\title{
Influence of deproteinised foliage fluid liquid biofertilizer on nitrate reductase activity of Eleusine coracana plants
}

\author{
Rajesh K. Jadhav', Gare Chhaya ${ }^{2}$ \\ 'Department of Botany, D. G. Ruparel College, University of Mumbai, Mahim 400016, Mumbai, Maharashtra, India, \\ ${ }^{2}$ Research Laboratory, Department of Botany, D. G. Ruparel College, University of Mumbai, Mahim 400016, Mumbai, \\ Maharashtra, India
}

Received: August 11, 2018 Accepted: October 14, 2018 Published: November 16, 2018

\section{*Corresponding Author:}

Rajesh K. Jadhav, Department of Botany, D. G. Ruparel

College, University of Mumbai, Mahim 400016, Mumbai,

Maharashtra, India

Email: rajesh.jadhav@ruparel.edu

\begin{abstract}
Deproteinised leaf extracts previously found favourably enhancing plant and fungi growth. Present attempt has been made to observe its influence in enhancing the enzyme nitrate reductase. Crop of Eleusine coracana was cultivated and treated by deproteined whey from the leguminous weed Cassia tora and its influence examined on the activity of the enzyme nitrate reductase by spectrophotometric method. Cassia tora crop was fractionated for the purpose to isolate crude leaf protein by heating the juice to $90^{\circ} \mathrm{C}$ which gave deproteinised leaf juice (DPJ). The crop growth was also compared with other monocotyledonous wheat, Sorghum and bajra crops. There was enhancement of nitrate reductase in wheat crop by the application of non leguminous Basella forage DPJ. There was lesser activity of nitrate reductase in Eleusine crop by the influence of Cassia tora DPJ probably because of the deficiency of element molybdenum in the utilised red soil for the growth of crops or allelopathy. Length and number of leaves of Eleusine crop was measured.
\end{abstract}

KEY WORDS: Eleusine, Deproteinised juice, Cassia tora, Nitrate reductase, seedlings, growth, nitrogen fixation.

\section{INTRODUCTION}

Out of the all enzymes in plants, Nitrate reductase is important one involving in the assimilation of exogenous nitrate [1,2]. Ionic and osmotic conditions also effects on nitrate reductase enzymes in tomato seedlings [3]. There was favourable effect of boron on nitrate reductase activity in sunflower seedlings [4]. Leaf Protease levels were higher for the low variety prior to flowering in wheat plants [5].

In earlier findings, when the seed are less viable for germination, DPJ induced and allowed the seedlings to grow fastly due to its nutrients and presence of hormones. There were variations of the effects of different DPJ on different seeds. In these experiments, Raddish DPJ induced the germination in Pumpkin and sunflower seeds. Colocasia DPJ induced the fenugreek, Macrotyloma, Eleucine, Sesame and Linum usitassimum seeds. While brinjal DPJ enhanced Cucurbita pepo seed germination. Crude protein content increased by lucerne DPJ treatment in Cyamopsis tetragonoloba seedlings [6]. It was studied that the juice fermentation of leaves of cauliflower reduces the protease enzyme by the process of anaerobic respiration [7]. Present study deals with the effect of DPJ prepared from the ethnic weed Cassia tora belongs from leguminoseae family on enzyme nitrate reductase activity in monocotyledonous Eleusine plants. The DPJ prepared from the non leguminous crop Basella alba treated for the activity of enzyme nitrate reductase on wheat crop. DPJ prepared from leguminous crops Phaseolus lunatus and cowpea treated to Sorghum and bajra plants respectively.

During the present investigation, the study of nitrate reductase by spectrophotometric analysis was taken into consideration in monocotyledonous non leguminous crop of Eleusine coracana leaves and compared with other cereal crops. During assimilation of nitrate in higher plants, the fundamental process is the reduction of nitrates to ammonia. This is achieved by two enzymes Nitrate Reductase (NR) and Nitrite reductase (NiR).

\section{MATERIALS AND METHODS}

The process of green crop fractionation (GCF) involves extraction of protein from green leaves of Basella alba L, Cassia tora L., Phaseolus lunatus L and cowpea (Vigna unguiculata L., walp) for use in human and animal nutrition. During GCF, fresh green leaves are macerated and subsequently pressed [8]. The leaf juice released due to the pressing is then heated to $95^{\circ} \mathrm{C}$, as a result

Copyright: $\odot 2018$ The authors. This article is open access and licensed under the terms of the Creative Commons Attribution License (http://creativecommons.org/licenses/by/4.0/) which permits unrestricted, use, distribution and reproduction in any medium, or format for any purpose, even commercially provided the work is properly cited. Attribution - You must give appropriate credit, provide a link to the license, and indicate if changes were made. 
of which, proteins in juice, coagulate to form a curd referred to as leaf protein concentrate (LPC). The LPC is isolated from remaining portion of leaf juice, called as deproteinised juice (DPJ), by filtration through cotton cloth. $100 \mathrm{ml}$ of the DPJ treatment was given by pouring in the pots consisting of red soil of grown seedlings of various crops at 3 days of intervals.

Nitrate reductase was estimated by following standard procedure.

\section{RESULTS AND DISCUSSION}

Table 1 indicates the $2.94 \%$ of the dry LPC obtained in the groundnut crop. While DPJ from juice obtained was 82 percent. The juice obtained from Cassia tora was more as compared with groundnut foliage. Therefore Cassia gave more production of DPJ which can be feasible for cultivators. They can give this natural DPJ treatment considering as manure (figure 2). In tribal areas, the Cassia tora is edible. As compared with groundnut leaves Cassia obtained more crude leaf protein (LP). The fresh crop weight of groundnut was found more than that of Cassia plants.

To calculate the Leaf protein concentrate (LPC), it gave $4.65 \%$ of the dry LPC from the $200 \mathrm{~g}$ of the Cassia tora crop. The deproteinised juice (DPJ) obtained was $55.71 \%$ in $700 \mathrm{ml}$ of the leaf extract. Figure 1 shows the bar graphical presentation of standard deviation indicating the DPJ percent in juice and LPC percent in fresh crop.

In earlier findings $[9,10]$, it was found that the leguminous Lucerne DPJ effected favourably on Cowpea (Vigna unguiculata.L. walp) crop growth inducing root nodulation. This indicated that nitrogen fixation taken place was at appreciable amount, as the protein content in plants raised because of the treatment by lucerne DPJ to cowpea. There was the enhancement in the number of leaves, dry matter and protein content from the grown green leafy crop. While in case of peas crop, the lethal dose of DPJ effect showed phytotoxicity [11]. Higher dose of Lucerne and Eichornia DPJ caused chromosomal aberrations in the root tips of Allium cepa and A. sativum $[12,13]$. Deproteinised plant juice also found favourable as the culture medium for fungi mycelial cell proliferation and secreting cell wall degrading hydrolytic enzymes.

Abscissic acid, auxin, and cytokinins have been closely linked to nitrogen signalling and are integrated to bring about changes

Tablel: Distribution of green crop fractionation byproducts of Cassia tora and Groundnut. In fresh weight of crop, LPC in percentage and in Juice obtained from pulp, DPJ obtained in percentage.

\begin{tabular}{llcc}
\hline No & GCF byproducts & Cassia tora (\%)S & Arachis hypogea (\%) \\
\hline 1. & Fresh weight of crop $(\mathrm{g})$ & $200(95.35)$ & $250(97.06)$ \\
2. & LPC dry matter $(\mathrm{g})$ & $9.3(4.65)$ & $7.36(2.94)$ \\
3. & Juice $(\mathrm{ml})$ & $700(44)$ & $400(18)$ \\
4. & Deproteinised Juice $(\mathrm{ml})$ & $390(56)$ & $330(82)$ \\
\hline
\end{tabular}

in physiology and morphology [14]. Nitrates inhibits gibberelin biosynthesis. During present investigation, the effect of DPJ made from leguminous plant Cassia tora showed significant difference in control and its treated parameters like number of leaves, length of the plants, dry biomass and the activity of the enzyme nitrate reductase.

Table 2 illustrates the statistical calculation which indicate the increase in the length and number of leaves in the Eleusine plants because of the Cassia tora DPJ treatment. This leguminous DPJ favoured the physical growth of the plants. Figure 3 shows the enhanced length of the plants by DPJ influence by line graphical presentation. Figure 4 shows the growth of Eleusine crop by the influence of Cassia tora DPJ.

Table 3 indicates the elucidation of the drastic increase in the activity of the enzyme nitrate reductase because of the treatment of non leguminous Basella alba DPJ to the wheat seedlings grown on red soil of konkan by statistical calculations. After the germination, when the first treatment of DPJ was given, few plants of Eleusine were vanished. Reason might be because of the constituents of Cassia tora DPJ, as it is the weed. But the remaining plants were more healthier than that of untreated pants. But the non leguminous crop Basella DPJ which was added to the soil thrice $(100 \mathrm{ml})$ showed plant growth stimulation and proper absorption by the seedling roots to regulate the glutamase synthase cycle and converted into organic compounds in the seedlings to form amino acids for

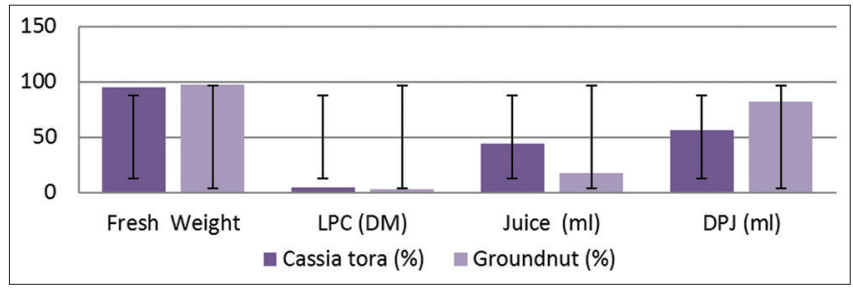

Figure 1: Comaparative graphical presentation (error bars with standard deviation) of the green crop fractionation products obtained in Cassia tora and groundnut crops

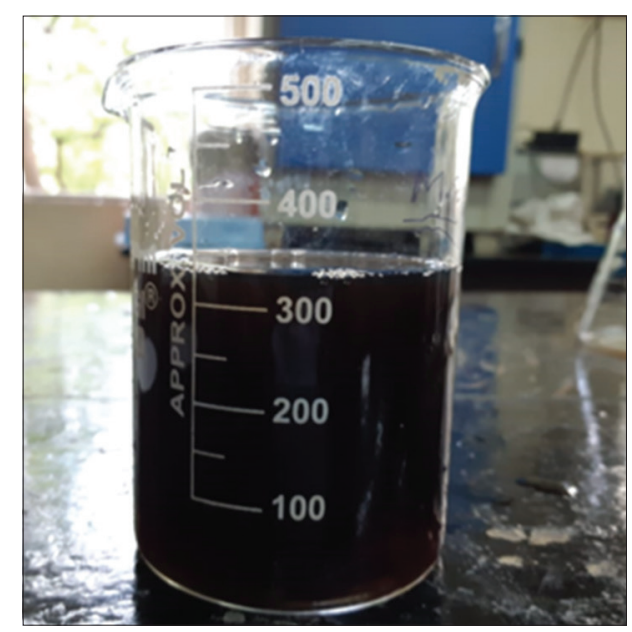

Figure 2: Deproteinised juice of Arachis hypogea by the process of green crop Fractionation (GCF). 
Table 2: Effect of Cassia tora weed DPJ on number of leaves and length of the Eleusine plants

\begin{tabular}{|c|c|c|c|c|}
\hline \multirow[t]{2}{*}{ No. } & \multicolumn{2}{|c|}{ Length of the plants } & \multicolumn{2}{|c|}{ Number of leaves } \\
\hline & Control & Cassia tora DPJ & Control & Cassia tora DPJ \\
\hline 1 & 4.5 & 6.5 & 2 & 3 \\
\hline 2 & 6 & 6.7 & 3 & 3 \\
\hline 3 & 4.9 & 5.1 & 3 & 3 \\
\hline 4 & 5.4 & 6.8 & 3 & 3 \\
\hline 5 & 5 & 7.2 & 2 & 3 \\
\hline 6 & 4 & 7.1 & 2 & 2 \\
\hline 7 & 5.8 & 6.2 & 2 & 2 \\
\hline 8 & 4.6 & 5.8 & 2 & 2 \\
\hline 9 & 6.2 & 7 & 3 & \\
\hline 10 & 5 & 6.7 & 2 & 3 \\
\hline 11 & 3.7 & 4.1 & 2 & 3 \\
\hline 12 & 4.5 & 5.2 & 2 & 3 \\
\hline Mean & 5 & 6 & 2 & 3 \\
\hline $\begin{array}{l}\text { Standard } \\
\text { deviation }\end{array}$ & 0.77 & 0.96 & 0.49 & 0.38 \\
\hline
\end{tabular}

Table 3: Effect of DPJ on nitrate reductase in various selected gramineae crops

\begin{tabular}{lllcc}
\hline No & Forage & DPJ & \multicolumn{2}{c}{$\begin{array}{c}\text { Nitrate reductase activity } \\
\text { (NRA) 0.D. xMF(0.32) } \mu \mathrm{g}\end{array}$} \\
\cline { 3 - 5 } & & Control & DPJ \\
\hline 1 & Jowar & Phaseolus lunatus & 0.188 & 0.281 \\
2 & Wheat & Basella alba & 0.004 & 0.048 \\
3 & Bajra & Vigna unguiculata.L. & 0.006 & 0.006 \\
4 & Eleucine & Cassia tora & 0.131 & 0.118 \\
& & Mean & 0.082 & 0.113 \\
& & Standard deviation & 0.092 & 0.121 \\
\hline
\end{tabular}

plant growth, proteins, nucleic acids, chlorophylls, alkaloids and vitamins by ammonification in plastids of wheat plants by nitrites. There was enhancement in the enzyme nitrate reductase activity by Basella DPJ on wheat plants. Basella forage seems rich in nitrogen content. In Spinach DPJ, (the other member of chenopodiaceae) when was taken into consideration [8], it was found that $2.95 \%$ of dry DPJ contained $2.91 \%$ of nitrogen content. While on the other hand, leguminous crop Cassia tora DPJ showed its adverse effect on decreasing the nitrate reductase activity in Eleusine crop. May be because of its phytotoxic effect and its allelochemicals. This result indicates that DPJ from Cassia tora weed was not suitable for Eleusine crop, despite it is leguminous. Table 3 indicates the increase in the nitrate reductase activity in Sorghum vulgare crop by the DPJ of Dolichos lablab crop. While in case of Vigna unguiculata DPJ, effect was unable to increase the nitrate reductase in Pennysetum typhoides. Might be because of the red soil as its nitrate reductase is also less in control. Figure 5 shows the standard deviation bar graphical presentation of the enzyme nitrate reductase performance by the influence of various DPJ on all the four cereal crops seedlings growth. It was observed that [8], $14.83 \%$ of dry fresh foliage of cowpea contained $2.78 \%$ of nitrogen content. There is no significant difference in the nitrate reductase among the DPJ treated and untreated pots of Pennysetum typhoides. Therefore cowpea DPJ had nitrate reductase but it coudnt had the potentiality to enhance the NR in bajra plants.

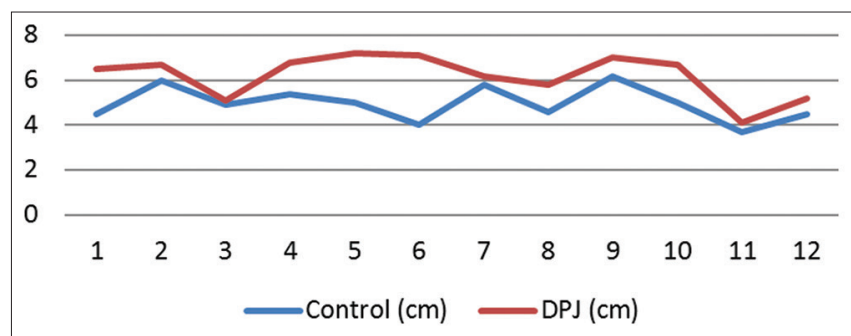

Figure 3: Effect of Cassia tora DPJ on length of Eleucine coracana plants

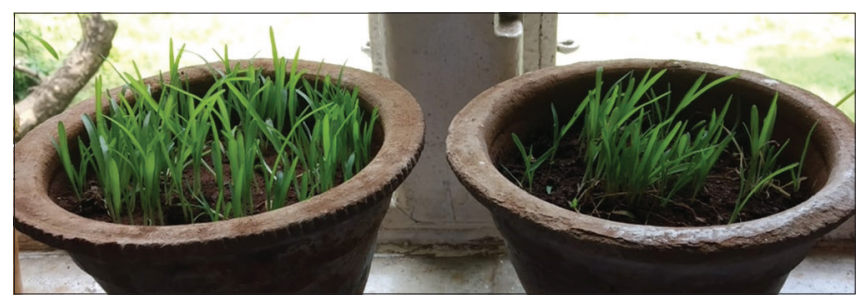

Figure 4: Photograph of the grown Eleusine crop by the effect of DPJ.

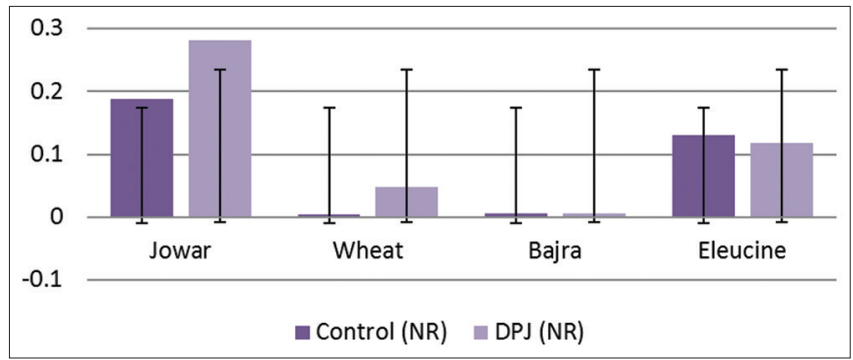

Figure 5: Effect of various DPJ on the nitrate reductase (NR) of various foliages of cereal crops by the error bars of standard deviation

In Eleusine coracana leaves, if the nitrate reductase is inactivated it will cause an accumulation of the toxic nitrite in the cells as per the observation during dark [15]. Therefore the decrease in nitrate reductase indicates the lack of nitrogen for protein synthesis and growth of the plants. Allelopathic chemicals in Cassia was responsible to inhibit NR. It was also probably because of the deficiency of molybdenum in the red soil which is helpful to absorb the nitrogen content. The element is required for metabolic processes other than the reduction of nitrate, perhaps in the formation of glutamic dehydrogenase, which is decreased in molybdenum deficient soil in case of bajra. Nitratre reductase can also be purified by PAGE [16]. Other enzymes like amylases productivity is also found on DPJ obtained from different crops [17].

\section{CONCLUSION}

In both jowar and wheat crops there was increase in the nitrate reductase content by the effect of leguminous and nonleguminous DPJ, whereas, leguminous DPJ of Cowpea was unable to enhance nitrate reductase in bajra crop. There was decrease in nitrate reductase in Eleusine coarcana because of weed plant Cassia tora DPJ despite it was of leguminoseae. Cassia tora can give approximately $\mathrm{lg}$ of crude protein in $2 \mathrm{~kg}$ of the vegetation. Therefore it is concluded that specific DPJ if 
used for treatment can have the efficacy in enhancing the nitrate reductase in specific crop i.e. there can be variation in the result by DPJ on different crops. The overall statistical mean value standard deviation of nitrate reductase showed enhancement by the influence of DPJ.

\section{ACKNOWLEDGEMENTS}

The author thanks to the Principal, D. G. Ruparel College, Mumbai affiliated to University of Mumbai to provide the laboratory facilities for the research work. The author express the deep sense of gratitude to Professor A.M. Mungikar, Dr. Babasaheb Ambedkar Marathwada University for giving the ideas of the work to be carried out.

\section{DECLARATION OF THE CONFLICT OF INTEREST}

The authors declares that there is no conflict of interest.

\section{REFERENCES}

1. HS Srivastava. Regulation of nitrate reductase activity in higher plants. Phytochemistry. 1980; 19 (5), 725-733

2. Mohd Mazid, Taqi Ahmed Khan, Firoz Mohammad. Role of nitrate reductase in nitrogen fixation under photosynthetic regulation. World Journal of Pharmaceutical research. 2012; 1 (3), 386-414.

3. P. Flores, MA. Botella., V. Martínez, A. Cerdá. Ionic and Osmotic Effects on Nitrate Reductase Activity in Tomato Seedlings. Journal of Plant Physiology. 2000; 156 (4) 552-557.

4. R. Kastori, N. Petrovic. Effect of boron on nitrate reductase activity in young 8 Sunflower plants. Journal of Plant Nutrition. 1989; 12, (5) 621-632.
5. Srinivas C. Rao, Lavoy I. Croy. Protease and nitrate reductase seasonal patterns and their relation to grain protein production of high vs. low protein wheat varieties. J. Agric. Food Chem. 1972; 20 (6), 1138-1141.

6. Rajesh K Jadhav. Response of seed germination and seedling growth by the deproteinised juice (DPJ) from various forages. Biochemical and Cellular Archives. 2018 c; 18 (1): 1181-1188.

7. Rajesh K Jadhav. Effect of Amylase and Protease enzymes on the yields of Leaf protein Concentrates (LPC) prepared by Fermentation of leaf Juice (CIBTech) Indian Journal of Plant Sciences. 2018 a; 7 (1), 42-52.

8. Rajesh K Jadhav. Fractionation Of The Foliages Obtained From Leguminous Species For Leaf Protein Preparation. Journal of Natura products and Plant Resources; Scholars Research Library. 2018 b; 9 (2): 1-7.

9. Jadhav RK, Mungikar AM.: Effect of Deproteinised Leaf Juice (DPJ) on growth of Cowpea. J. Aquatic Biology. 1998 a; 13 (1-2), 144-145.

10. Rajesh K Jadhav. Effect of deproteinised Juice (DPJ) on Root Growth And Nodulation of Leguminous. Plants. Journal Bionanofrontier. 2017; 10 (1), 84 - 87.

11. Rajesh K Jadhav Phytotoxic Effect Of Deproteinised Leaf Juice (DPJ) of Lucerne (Medicago sativa L) On Pea (Pisum sativum. L) Bioinfolet. 2009 a; 6 (3), 240 - 241.

12. Jadhav RK, Mungikar AM. Mitotic Inhibition and Chromosomal Abberations Induced by Deproteinised Leaf Juice Of Medicago sativa.L in Root tips of Onion (Allium cepa. L). Int Journal Mendel.1998 b; $15(1-2), 21-22$

13. Rajesh K.Jadhav Effect Of Deproteinised Juice From Eicchornia crassipes. L On Mitotic Cell Division. Bioinfolet. 2009 b; 6 (3), 246-248.

14. Alena Gaudinov Á.The effect of cytokinins on nitrate reductase activity. Biologia Plantarum 1990; 32(2): 89-96.

15. Burgi Riens, Hans Walter Heldt. Decrease of Nitrate Reductase Activity in Spinach Leaves during a Light-Dark Transition. Plant Physiol. 1992; 98, 573-577.

16. Wilbur H. Campbell, Jill L. Remmler. Regulation of Corn Leaf Nitrate Reductase I. Immunochemical Methods for Analysis of the Enzyme's Protein Component. Plant Physiol. 1986 ; 80 (2) : 435-441.

17. Sayyed IU. Production of amylase on deproteinised leaf juice prepared from different Plants. Plant Sciences Feed, 2014; 4 (4), 31-35. 